\title{
Effect of woodland patch size on rodent seed predation in a fragmented landscape
}

\author{
Jon Loman
}

Loman, J. 2007. Effect of woodland patch size on rodent seed predation in a fragmented landscape. - Web Ecol. 7: 47-52.

\begin{abstract}
Predation on large woody plant seeds; chestnuts, acorns and sloe kernels, was studied in deciduous forests of two size classes: small woodlots ( $<1 \mathrm{ha}$ ) and large woods (at least 25 ha) in southern Sweden. Seeds used for the study were artificially distributed on the forest ground and seed predation measured as seed removal. Predation rate was similar in both types of woods. However, rodent density was higher in small woodlots and a correction for differences in rodent density showed that predation rate per individual rodent was higher in the large woods. This suggests that the small woodlots (including the border zone) and their adjacent fields have more rodent food per area unit. A small woodlot cannot be considered a representative sample of a large continuous forest, even if the habitats appear similar. There was a strong effect of rodent density on seed predation rate. This suggests that rodents are major seed predators in this habitat.
\end{abstract}

J.Loman (jon.loman@zooekol.lu.se),Dept Animal Ecology, Lund Univ., SE-22362 Lund, Sweden.

The modern agricultural landscape mostly consists of large and homogeneous fields where patches of non-agricultural land are inbedded between these. Because the landscape in prehistoric times was dominated by these, usually forested, habitats, this process has been called fragmentation and the present landscape a fragmented landscape (Blondel 1980, Bailey et al. 2002). If this dynamic aspect is disregarded, the landscape can simply be referred to as heterogeneous. However, the process is real and far from halted, and the intensification of agriculture has continuously reduced the non-cropped area through present time (Agger and Brandt 1988). One region where the process has proceeded far is the southern part of the province of Scania in southern Sweden, where the present study has been conducted.

Fragmentation is a cause for concern with regards to conservation. It may be that natural habitat types are preserved but only in small pieces. This can lead to the elimination of animal species that require large continuous home ranges or have limited dispersal capabilities. This problem has been paid much attention (Andrén et al. 1985, Angelstam 1986, Nilsson 1978, Lahti 1985, Nupp and Swihart 2000). Recently, attention has also been directed to the effect of patch size on different ecological processes (Turner 1989, Murcia 1995, Redpath 1995, Bowers et al. 1996, Ries et al. 2004, Hulme and Kollmann 2005). Changes in these processes may in turn be the cause of species eliminations in small patches.

In this study, I examined the process of seed predation in deciduous forests. I previously found that rodents are the major seed predators in this habitat and that they may in a short time remove almost all seeds from the forest ground (Loman 2006). There are several common rodent species in temperate deciduous forests that feed on seeds during autumn (Hoffmeyer 1976, Jensen 1982, Angelstam et al. 1987, González et al. 1989, Wolff 1996, Ostfeld et al. 1997, Ivan and Swihart 2000, McCormick and Meiners 2000, Plucinski and Hunter Jr 2001, Díaz and Alonso 2003, den Ouden et al. 2005). Therefore, seed predation is in this study analysed in relation to small rodent 
abundance. Seed predation is here studied by examining seed removal. Most removed seeds are probably eaten; however, some are cached and may later be eaten or may germinate (Iida 1996, Hulme and Borelli 1999). From a plant perspective, the effect of seed predation may thus be complex.

The question is thus: assume that a small patch of deciduous forest is left uncut (or created by planting) in a "matrix" of cropped fields and that the taxonomic and structural characteristics of the forest appear similar to those in a large patch. Then, are the ecological processes in that small patch unaffected by the small size of the patch and the influence of the surrounding matrix? If not, and if the patch is supposed to serve a conservation purpose, it may be that all that one intends to preserve will not be preserved. Also, if the dynamics with respect to seed survival differs from that in continuous forest, this may have a long term effect on the tree species dynamics in the patch. Rodent seed predation has indeed been shown to have a profound effect on the flora of a habitat (Brown and Heske 1990, Santos and Tellería 1994, Howe and Brown 2000, Fuentes 2000, Manson et al. 2001, Gomez et al. 2003, Gulias et al. 2004).

I ask the posed question from two perspectives. First, I consider all available deciduous woods in the southwestern part of the Scania province. Based on a sample of this, I describe the fate of seeds in relation to patch size. I do not correct for differences in number of rodents actually present in the different patches that may exist among the plot size categories. However, the result reflects any differences actually found in the study area, within the chosen habitat category. Secondly, I correct for differences in rodent density. The results that emerge after such a correction may be considered to have a broader generality for understanding effects of landscape pattern on ecological processes than those found with the first approach.

\section{Methods}

\section{Study area and plot layout}

The study was performed in the central and southwestern parts of the Scania province, southern Sweden, in 1985, 1986 and 1987.

There were altogether 49 "study plots". They all had an almost closed canopy of deciduous trees. They were situated in two classes of "woodland patches". Small patches were small habitat islands, ranging between 0.04 ha and 0.42 ha in size. The whole patch was used as one study plot. There were 25 small patches. Large patches were isolated woods, between 25 ha and 35 ha in size, or were part of continuous woods in a landscape with a mosaic of forest, meadows and small fields. Two study plots of $50 \times 50$ $\mathrm{m}$ each and situated at least $200 \mathrm{~m}$ apart from each other were used in each large patch. All study plots in large patches were situated at least $100 \mathrm{~m}$ from the patch border to open fields. There were 12 such patches, and thus 24 study plots in large patches.

I used eight plots in small patches (nine in 1987) and eight in large patches each year. For the statistical tests, each small patch represented one analytical unit. For large patches, the mean value of the two plots was used because there could be a dependency between the two plots in one patch. Thus, there were 33 analytical units in total.

All study plots supported a rich deciduous forest. The only obvious difference in habitat was the fact that plots in small woodlots usually had a dense bush layer in the border zone at the few meters of the woodlot closest to the surrounding fields. The patches were surrounded by open fields, usually cropped.

All censuses, detailed below, were carried out in the plots on a grid basis. One grid point was located at every $10 \mathrm{~m}$. Thus, there were 36 grid points $(6 \times 6)$ in each $50 \times$ $50 \mathrm{~m}$ plot in large patches. These grid points were used for small mammal trap sites, seed predation experiments and censuses of woody plants. In small patches, the number of grid points varied, depending on patch size. Basically, there was one grid point every $10 \mathrm{~m}\left(100 \mathrm{ha}^{-1}\right)$ in these plots. These grid points were used for trapping small mammals. To increase resolution in the small patches, seed predation experiments and plant censuses, but not rodent captures, were also performed at intermediate grid points $(\mathrm{a} 5 \times 10$ $\mathrm{m}$ grid). Grid points in the small patches ranged from ten in a 0.04 ha woodlot to 44 in a 0.26 ha woodlot.

\section{Seed predation}

A set of three seeds, namely a chestnut Aesculus hippocastanum, an acorn Quercus robur and a sloe Prunus spinosa kernel were placed onto the ground, exactly at each grid point. This was done in the autumns of 1985 (30 Oct - 11 Nov) and 1986 (16 - 19 Oct). In autumn 1987 (31 Oct -3 Nov) only a chestnut and a sloe kernel were used. The sites were revisited after two days. The proportion of seeds removed or visibly eaten were scored. The proportion removed or eaten (collectively considered predated) of the three seed types was highly inter-correlated. The "ranking" of the different sites by the three predation rates yielded a Kendall coefficient of concordance of 0.917 (Friedman test statistics is $74.3, \mathrm{DF}=27, \mathrm{p}<0.001$ ). Thus, in all future analyses I will use the average of these three (or for 1987, two) numbers as a measure of seed predation in each plot.

\section{Rodents}

Rodents were live trapped in October each year $(22-29$ Oct 1985; 9 - 16 Oct 1986; 12 - 19 Oct 1987). Each trapping period lasted for five days; the traps were set on 
day one and checked on day two to five. All animals captured were individually marked and released. The number of different individuals trapped in a plot was used as an index of rodent numbers in that plot and that number was divided by the number of traps $(=$ ha $\times 100)$ to come up with an index of density.

Rodents of three granivorous species, yellow-necked mouse Apodemus flavicollis, wood mouse A. sylvaticus, and bank vole Clethrionomys glareolus, were trapped in large numbers during the study. Also one field vole Microtus agrestis was trapped but will not be considered further.

\section{Vegetation}

At each grid point, the canopy species were recorded, including all woody trees and bushes. When there were several layers of different species, they were all scored. The top height of the canopy above the grid point was also recorded.

\section{Statistical tests}

Predation rates were arcsine-squareroot transformed and rodent densities were log transformed. Year was treated as a random factor and patch size as a fixed factor in the twoway ANOVAs.

\section{Results}

\section{Seed predation}

Predation varied considerably among plots. However, it was not significantly affected by year (two-way ANOVA $\left.\mathrm{F}_{2,32}=0.025, \mathrm{p}=0.98\right)$ or patch size $\left(\mathrm{F}_{1,32}=0.06, \mathrm{p}=0.94\right)$ (Fig. 1). Although there was some variation among years for large and small patches (1985: $75 \%$ vs $54 \%, 1986$ : $64 \%$ vs $61 \%, 1987: 51 \%$ vs $67 \%$, respectively), the interaction was not significant $\left(\mathrm{F}_{2,31}=1.15, \mathrm{p}=0.31\right)$.

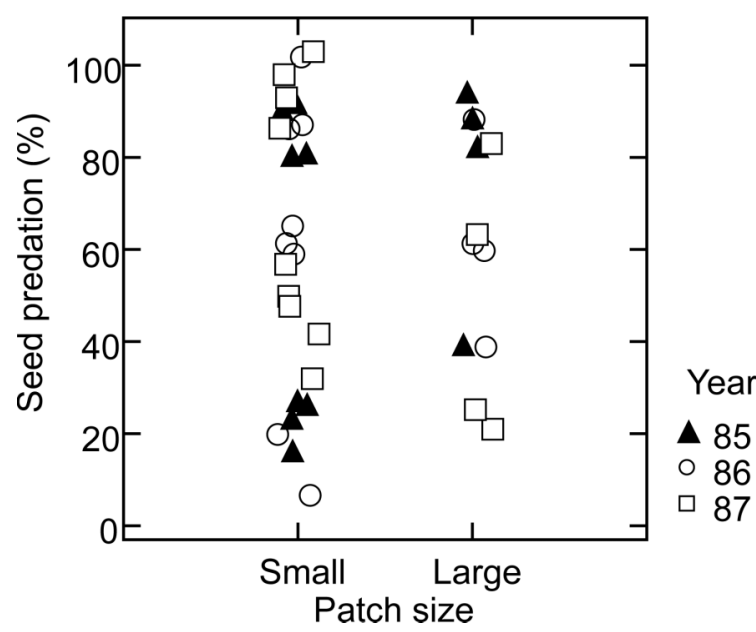

Fig. 1. Seed predation rates.

\section{Rodent density}

Rodent density was highest in the small patches for all three common species (Fig. 2). This difference was significant for the wood mouse and for all rodents taken together (Table 1).

\section{Seed predation corrected for rodent density}

Predation rates were similar for patches of both size classes, but a different pattern emerged when correcting for rodent density (Fig. 3). At a given rodent density, predation rate was highest in the large patches. There were significant effects of both patch size and rodent density on predation rate (Table 2 ).

\section{Vegetation}

All plots represented deciduous forest on a rich soil with a more or less continuous herb layer. Still, there were some

Table 1. Effect of year and patch size on rodent density indices according to two-way ANOVAs. All interactions were non significant and are not included in this test.

\begin{tabular}{lllll}
\hline & \multicolumn{2}{c}{ Year effect } & & \multicolumn{2}{c}{ Patch size effect } \\
\cline { 2 - 3 } \cline { 5 - 5 } & $\mathrm{F}_{2,33}$ & $\mathrm{p}$ & $\mathrm{F}_{1,33}$ & $\mathrm{p}$ \\
\hline A. flavicollis & 7.76 & 0.002 & 0.23 & 0.64 \\
A. sylvaticus & 3.80 & 0.033 & 9.27 & 0.005 \\
C. glareolus & 0.73 & 0.49 & 0.09 & 0.77 \\
All rodents & 1.11 & 0.34 & 6.200 & 0.018 \\
\hline
\end{tabular}




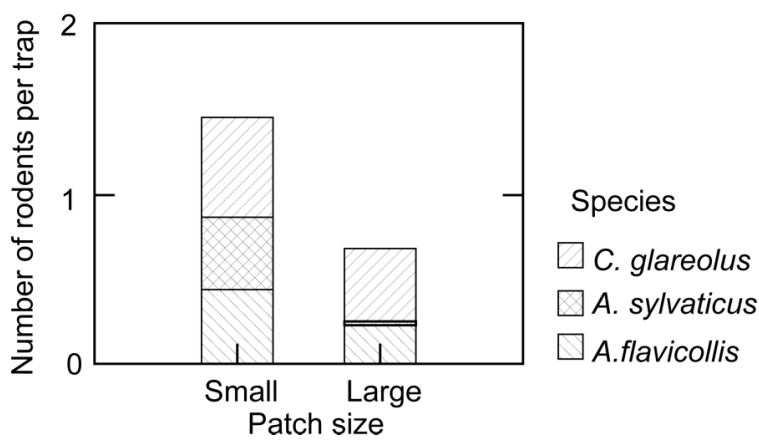

Fig 2. Indices of rodent density. The index is the number of individual rodents captured in a site (each individual may have been captured one to four times, but it is counted as one) divided by the number of traps at the site (with a density of $100 \mathrm{ha}^{-1}$ ).

differences between large and small plots (Table 3). Plots in large patches had the highest canopy. The number of woody species per grid point was similar in both patch categories. Species with large seeds that are important as rodent food (beech, oak, hazel, ash) were most common in large patches (Table 3). However, the difference was significant only for hazel.

\section{Discussion}

\section{Effects of patch size on predation}

There were no average differences between large and small patches in predation on the seeds provided. Could this be a bias because more seeds per area unit were provided to plots in the small patches, masking any real area effects? The seeds were provided during the time of natural seedfall of acorns and nuts. The density of artificial seeds was much lower than that of naturally occurring seeds so it is

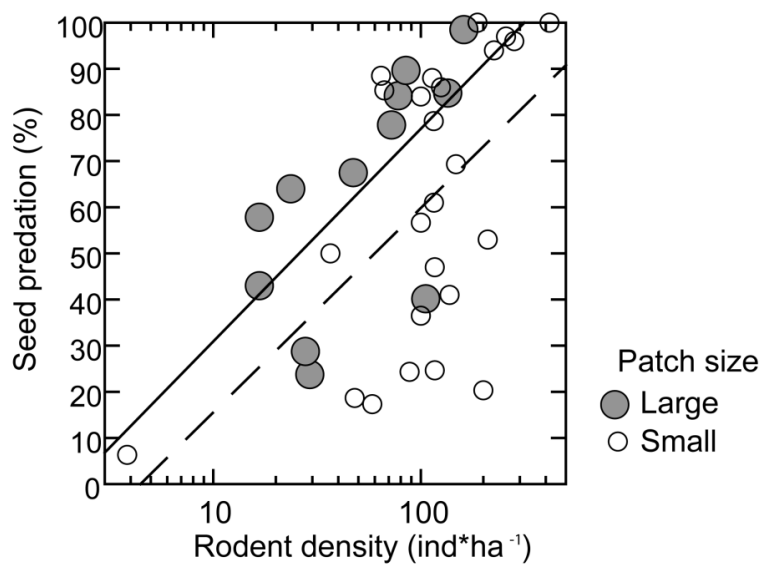

Fig 3. Seed predation in relation to rodent density.
Table 2. Three-way analysis of covariance, testing for effects on seed predation. Interactions were not significant and are not included in the tests.

\begin{tabular}{llll}
\hline & DF & F & p \\
\hline Year & $2: 32$ & 0.57 & 0.57 \\
Patch size class & $1: 32$ & 4.38 & 0.044 \\
Rodent density index & $1: 32$ & 22.8 & $<0.001$ \\
\hline
\end{tabular}

not likely that seed numbers provided in small patches satiated demand and thus reduced consumption per rodent.

Contrary to what was found in this study, other studies actually suggest higher rodent seed predation rates at forest edges (McCormick and Meiners 2000, Donoso et al. 2003, Tallmon et al. 2003). In another case this was true for rodent seed predation but offset by higher bird seed predation in large forests (Santos and Tellería 1994). Corresponding compensations were found by Orrock et al. (2003) in a system where patches differed by connectivity. The difference between these studies and mine could be due to actual differences in individual predation rates or to a higher relative rodent density in my large study patches.

\section{Correcting for rodent density}

Consumption of provided seeds per rodent was least in the small patches. The capture schemes used could potentially introduce a bias for this effect. With respect to yellownecked mice and bank voles that do not normally venture into the open fields, the plots in small patches can be considered a closed system (Loman 1991), that is completely covered by the trap grid. In contrast, plots in the large patches had a trap grid that was open in the respect that the outer rows of the capture grid could attract rodents with home range centre outside the plot. However, the effect of this bias should be that the densities in large plots are overestimated; thus, the pattern found (Fig. 3) should be a conservative estimate of the real pattern. For wood mice, all trap plots are equally open, also those in small patches, as this species is about as abundant in fields as it is in woodlots (Green 1979, Loman 1991, Ouin et al. 2000).

This suggest that rodents living in this habitat, despite being at least as numerous as those in larger patches, were less food stressed than those in other habitats studied. Good food conditions in small forest patches may explain why Nupp and Swihart (1996) found an inverse relation between patch size and mouse Peromyscus leucopus density (like I found a tendency for wood mice) and between patch size and mouse body weight. Also Tellería et al. (1991), Garía et al (1998) and Díaz et al. (1999) found an inverse relationship between wood mouse density and patch size. They explained this by improved habitat conditions as forest fragment size decreased, in agreement with my suggestion. However, findings by Díaz and Alonso 
Table 3. Characteristics of woods in the two patch size classes. "Layers" is the averge number of tree species above a sampling grid point.

\begin{tabular}{|c|c|c|c|c|c|c|}
\hline & \multirow[b]{2}{*}{$\begin{array}{l}\text { Canopy } \\
\text { height (m) }\end{array}$} & \multirow[b]{2}{*}{ Layers } & \multicolumn{4}{|c|}{$\%$ of grid points covered } \\
\hline & & & Beech & Oak & Hazel & Ash \\
\hline Small & 14.1 & 1.2 & 0.19 & 0.20 & 0.01 & 0.12 \\
\hline Large & 18.6 & 1.2 & 0.46 & 0.26 & 0.05 & 0.07 \\
\hline $\mathrm{t}_{43}$ statistic & 3.21 & 0.17 & 2.60 & 0.63 & 2.48 & 0.86 \\
\hline $\mathrm{p}$ & 0.002 & 0.87 & 0.013 & 0.53 & 0.017 & 0.40 \\
\hline
\end{tabular}

(2003) suggested that wood mice may be suffering a food shortage also in small forest fragments. My data does not allow a separation among seed predation by the three rodent species. However, the fact that only the wood mouse was significantly more common in the small patches gives reason to restrict my suggestion about habitat quality to this species.

\section{Effects of tree and bush species}

There were several tree and bush species present in the studied plots. Because I do not know their relative value as rodent food resource, it is no feasible to statistically correct for the woody plant species effect. However, it is unlikely that the effects found on seed predation rate after compensation for rodent density was due to a superabundance of "natural", large seeds as an alternative source of food in small patches. On the contrary, among the most abundant seed plants, density was always least in the small patches where the predation rate on seeds also was least, contrary to what one could expect if the pattern had been due to the availability of natural large seeds.

\section{Conclusion}

Why were food conditions favourable in the present small patches? An obvious possibility, the availability of large seed trees and bushes, does not seem to be the explanation. However, other alternative food could be found in the surrounding fields, at least for wood mice. Previous work in this and other areas has shown that wood mice are abundant also in the cropped fields surrounding the habitat patches (Green 1979, Loman 1991, Díaz et al. 1999). Wood mice hoard waste grain that are found in abundance after harvest in these fields (personal data). Thus, the results give some support the hypothesis that individual wood mice forage both in woodlots and in the surrounding fields (Díaz et al. 1999). However, bank voles and yellow-necked mice rarely venture out into these fields. Also, the border zone, the part of the patch immediately adjacent to the fields, may be especially productive with respect to such rodent food, e.g. various herb species that were not recorded in this study.
Acknowledgements - I thank Kerstin Persson for help with vegetation analyses and seed counts in the field. Bodil Enoksson provided helpful comments to the presentation. The study has been financed by the National Environmental Protection Board and the Swedish Council for Forestry and Agricultural Research.

\section{References}

Agger, P. and Brandt, J. 1988. Dynamics of small biotopes in Danish agricultural landscapes. - Landscape Ecol. 1: 227240.

Andrén, H. et al. 1985. Differences in predation pressure in relation to habitat fragmentation: an experiment. - Oikos 45: 273-277.

Angelstam, P. 1986. Predation on ground-nesting birds' nests in relation to predator densities and habitat edge. - Oikos 47: 365-373.

Angelstam, P. et al. 1987. Distribution borders of field mice Apodemus: the importance of seed abundance and landscape composition. - Oikos 50: 123-130.

Bailey, S. A. et al. 2002. Species presence in fragmented landscapes: Modelling of species requirements at the national level. - Biol. Conserv. 108: 307-316.

Blondel, J. 1980. Landscape fragmentation and community organization. - Acta Oecol. 1: 91-100.

Bowers, A. M. et al. 1996. Use of space and habitat by meadow voles at the home range, patch and landscape scales. - Oecologia 105: 107-115.

Brown, J. H. and Heske, E. J. 1990. Control of a desert-grassland transition by a keystone rodent guild. - Science 250: 17051707.

den Ouden, J. et al. 2005. Jays, Mice and Oaks: Predation and dispersal of Quercus robur and Q. petrea in north-western Europe. - In: Forget, P. M. et al. (eds.), Seed fate. Predation, dispersal and seedling establishment. CABI Publishing. pp. 223-239.

Díaz, M. and Alonso, C. L. 2003. Wood mouse Apodemus sylvaticus winter food supply: density, condition, breeding and parasites. - Ecology 84: 2680-2691.

Díaz, M. et al. 1999. Efects of forest fragmentation on the winter body condition and population parameters of an habitat generalist, the wood mouse Apodemus sylvaticus: a test of hypotheses. - Acta Oecol. 20: 39-49.

Donoso, D. S. et al. 2003. Effects of forest fragmentation on the granivory of different sized seed. - Biol. Conserv. 115: 63-70.

Fuentes, M. 2000. Frugivory, seed dispersal and plant community ecology. - Trend Ecol. Evol. 15: 487-488. 
García, F. et al. 1998. Edge effects and patterns of winter abundance of wood mice Apodemus sylvaticus in Spanish fragmetned forests. - Acta Theriol. 43: 255-262.

Gomez, J. M. et al. 2003. Impact of vertebrate acorn- and seedling-predators on a Mediterranean Quercus pyrenaica forest. For. Ecol. Manage. 180: 125-134.

González, L. A. et al. 1989. The effects of seed availability on population density of Oryzomys in southern Chile. - J. Mammal. 70: 401-403.

Green, R. 1979. The ecology of wood mice (Apodemus sylvaticus) on arable farmland. - J. Zool., Lond. 188: 357-377.

Gulias, J. et al. 2004. Critical stages in the recruitment process of Rhamnus alaternus L. - Ann. Bot. 93: 723-731.

Hoffmeyer, I. 1976. Experiments on the selection of food and foraging site by the mice Apodemus sylvaticus and A. flavicollis (Melchior, 1834). - Säugetierk Mitt. 24: 12-124.

Howe, H. F. and Brown, J. S. 2000. Early effects of rodent granivory on experimetnal fromcommunities. - Ecol. Appl. 10: 917-924.

Hulme, P. E. and Borelli, T. 1999. Variability in post-dispersal predation in deciduous woodland: relative importance of location, seed species, burial and density. - Plant. Ecol. 145: 149-156.

Hulme, P. E. and Kollmann, J. 2005. Seed predator guilds, spatial variation in post-dipersal seed predation and potential effects on plant demography: a temperate perspective. - In: Forget, P. M. et al. (eds.), Seed fate. Predation, dispersal and seedling establishment. CABI Publishing, pp. 9-30.

Iida, S. 1996. Quantitative analysis of acorn transportation by rodents using magnetic locator. - Vegetatio 124: 39-43.

Ivan, J. S. and Swihart, R. K. 2000. Selection of mast by granivorous rodents of the central hardwood forest region. - J. Mammal. 81: 549-562.

Jensen, T. S. 1982. Seed production and outbreaks of non-cyclic rodent populations in deciduous forests. - Oecologia 54: 184-192.

Lahti, T. 1985. The SLOSS principle and conservation practice: an example. - Oikos 44: 369-370.

Loman, J. 1991. The small mammal fauna in an agricultural landscape in southern Sweden with special reference to the wood mouse Apodemus sylvaticus. - Mammalia 55: 91-96.

Loman, J. 2006. Seed predators in south Swedish deciduous woods: a field experiment. - Acta Zool. Sinica. 52: 462-468.

Manson, R. H. et al. 2001. Long-term effects of rodent herbivory on tree invasion dynamics along forest-field edges. - Ecology 82: 3320-3329.
McCormick, J. T. and Meiners, S. J. 2000. Season and distance from forest-old field edge affects seed predation by whitefooted mice. - Northeastern Nat. 7: 7-16.

Murcia, C. 1995. Edge effects in framented forests: implications for conservation. - Trend Ecol. Evol. 10: 58-62.

Nilsson, S. G. 1978. Fragmented habitats, species richness and conservation practice. - Ambio 26-27.

Nupp, T. E. and Swihart, R. K. 1996. Effects of forest patch area on population attributes of white-footed mice (Peromyscus leucopus) in fragmented landscapes. - Can. J. Zool. 74: 467472.

Nupp, T. E. and Swihart, R. K. 2000. Landscape-level correlates of small-mammal assemblages in forest fragments of farmland. - J. Mammal. 81: 512-526.

Orrock, J. L. et al. 2003. Spatial ecology of predator-prey interactions: corridors and patch shape influence seed predation. Ecology 84: 2589-2599.

Ostfeld, R. S. et al. 1997. Effects of rodent on survival of tree seeds and seedlings invading oldfields. - Ecology 78: 15311542.

Ouin, A. et al. 2000. Spatial dynamics of the wood mouse (Apodemus sylvaticus) in an agricultural landscape under intensive use in Mont Saint Michel Bay (France). - Agr. Ecosyst. Environ. 78: 159-165.

Plucinski, K. E. and Hunter, M. L. Jr 2001. Spatial and temporal patterns of seed predation on three tree species in an oak-pine forest. - Ecography 24: 309-317.

Redpath, S. M. 1995. Habitat fragmentation and the individual: tawny owls Strix aluco in woodland patches. - J. Anim. Ecol. 64: 652-661.

Ries, L. et al. 2004. Ecological responses to habitat edges: mechanisms, models, and variability explained. - Annu. Rev. Ecol. Syst. 35: 491-522.

Santos, T. and Telleria, J. L. 1994. Influence of forest fragmentation on seed consumption and dispersal of Spanish juniper Juniperus thurifera. - Biol. Conserv. 70: 129-134.

Tallmon, D. A. et al. 2003. Of mice and Trillium: cascading effects of forest fragmentation. - Ecol. Appl. 13: 1193-1203.

Tellería, J. L. et al. 1991. Abundance and food searching intensity of wood mice (Apodemus sylvaticus) in fragmented forests. J. Mammal. 72: 183-187.

Turner, M. G. 1989. Landscape ecology: The effect of pattern on process. - Annu. Rev. Ecol. Syst. 20: 171-197.

Wolff, J. O. 1996. Population fluctuations of mast-eating rodents are correlated with production of acorns. - J. Mammal. 77: 850-856. 